\title{
Internal Control Systems and Performance of Life Insurers: Ghanaian Case
}

\author{
Ashiagbor, A.A ${ }^{1} \quad$ Ayamga, A.T. ${ }^{2} \quad$ Adzagbre, C.K. ${ }^{3}$ \\ 1.Department of Banking and Finance, University of Professional Studies, Accra \\ 2.Department of Accounting, University of Professional Studies, Accra \\ 3.Department of Business Administration, KAAF University College, Accra
}

\begin{abstract}
Life insurance companies are very crucial in the mobilisation of financial resources in a country, and therefore have a tremendous impact on the economic growth and financial stability of the country. The importance of internal control mechanisms in achieving these goals cannot be overemphasized. Despite the growing trend in internal control systems in financial institutions, there is little knowledge on the internal control practices that exist within life insurance companies in Ghana and how these influence their performances. It is against this background that this study set out to fill this gap. The main objective of this study is to examine the effect of internal control mechanisms on the performance of life insurers in Ghana. The multiple regression analysis was used to establish the statistical relationship between the COSO framework of internal control system and the performance of the Ghanaian life insurers. The findings from this study showed that internal control mechanisms have positive and unique contribution to explaining the performance of life insurance companies in Ghana. The study recommends among others that the life insurance firms need to improve upon the core principles of the various components of the COSO internal control integrated framework. For instance, with regards to the control environment, the insurance firms should demonstrate commitment to integrity and ethical values; they should exercise oversight responsibility, establish structure, authority, and responsibility, demonstrates commitment to competence, and enforce accountability throughout the firms.
\end{abstract}

Keywords Ghana life insurance industry, internal control systems, firm performance

DOI: $10.7176 /$ RJFA/11-18-11

Publication date:September $30^{\text {th }} 2020$

\section{Introduction}

The importance of internal control system in relation to achieving an organization's goals cannot be overemphasized (Badoo, Hammond \& Oppong, 2020; Brennan \& Soloman, 2008). The role of life insurance companies are very crucial in the mobilisation of financial resources in a country, and therefore have a tremendous impact on the economic growth and financial stability of the country.

In order to achieve organisation goals the entity, of whichever form or size, should put in place system of controls in order to achieve its objectives (Widyaningsih, 2015; Mawanda, 2008). A system of effective internal controls is a critical component of company management and a foundation for the safe and sound operation of organizations as against an ineffective internal control that may results in ineffective programs and eventually leading to losses (Chebungwen \& Kwasira 2014).

According to Amissah (2017) and Mawanda (2008), internal control is processes designed and effected by those charged with governance, management, and other personnel to provide reasonable assurance about the achievement of an entity's objectives with regard to reliability of the financial reporting, effectiveness and efficiency of operations and compliance with applicable laws and regulations.

Internal controls are put in place to ensure safe custody of all institutional assets; to avoid misuse or misappropriation of assets and to detect and safeguard company's resources against probable frauds. The Committee of Sponsoring Organizations of the Treadway Commission (COSO, 2013) developed an internal control integrated framework or model for evaluating internal controls. The COSO framework point out that properly instituted systems of internal control improve the reporting process and also gives rise to reliable reports which enhances the accountability function of management of an entity. This model has been adopted as the generally accepted framework for internal control and is widely recognized and use by many researchers and practitioners (Badoo et al 2020; Amissah,2017; Abdi, 2015) as the definitive standard against which organizations measure the effectiveness of their systems of internal control.

The COSO model defines internal control as "a process effected by an entity's board of directors, management and other personnel designed to provide reasonable assurance of the achievement of objectives in the following categories: operational effectiveness and efficiency, financial reporting reliability, applicable laws and regulations compliance.

In an effective internal control system, the following five components namely control environment (CE), risk assessment (RA), control activities (CA), information and communication(IC), and monitoring work (MA) to support the achievement of an entity's mission, strategies and related business objectives. These components work 
to establish the foundation for sound internal control within the company through directed leadership, shared values and a culture that emphasizes accountability for control. The various risks facing the company are identified and assessed routinely at all levels and within all functions in the organization. Control activities and other mechanisms are proactively designed to address and mitigate the significant risks. Information critical to identifying risks and meeting business objectives are accordingly communicated through established channels across the company. The entire system of internal control is monitored.

A sound internal control helps an organization to prevent frauds, errors and minimize wastage, custody of assets is strengthened, it provides assurance to the management on the dependability of accounting data, eliminates unnecessary suspicion and helps in maintenance of adequate and reliable accounting records (Widyaningsih, 2015)

Firm performance is an indicator that helps to evaluate and measure how an organization succeeds in realizing business objectives to all its stakeholders (Kinyua, Gakure, Gekara, Orwa, 2015). Performance measures have been viewed from several perspectives by academic and professional researchers. For instance, Bourne, Neely, Mills and Platts (2003) define performance measurement as metrics used to quantify and compute an action's efficiency and effectiveness. Performance assessment, according to Smith (2005), could be financial or nonfinancial. Financial performance measures are those which use financial performance indicators such as profit margin, return on assets and return on equity in measuring organisational performance.

Financial performance measures have mostly been done using three indicators; return on assets, return on equity and return on sales. Moreover, researchers have opined that the current emphasis on traditional performance measures such as return on investment or net earnings diverts firm's attention from nonfinancial factors such as customer satisfaction, product quality, productivity and business efficiency (Yousef, 2017; Mary, Albert, \& Byaruhanga,2014).

Non-financial performance measures, on the other hand, rely on performance indicators that are non-financial such as quality of service, resource utilization, innovation and competitive performance (Epstein \& McFaralan, 2011). A study conducted by Hakkak and Ghodsi (2015) revealed that implementation of nonfinancial performance measures in organizations has a significant positive effect on firms' competitive advantage and sustainability.

It has severally being noted in literature that there is that perception that non-financial measures are better forecasters of a long run firm's performance, as well the business leaders to monitor and assess their company's efficiently (Abdi, 2015; Kaplan, 2014; Palfi \& Muresan, 2009). Even though nonfinancial performance may have lower measurement accuracy, but they focus on components that directly relate to operations that are within the control of the management (Yousef, 2017).

In the case of life insurance industry, it is appropriate from both practitioners and researchers perspectives to adopt different measures of organizational performance. As a social business, life insurers have both financial as well as social objectives. Given this, the performance of commercial life insurers should be measured by using not only financial but also non-financial or social measures (Eniola \& Akinselure, 2016; Abdi, 2015).

Internal controls and performance of organisations have been studied by few scholars. The unanswered questions that need urgent attention are whether there is significant relationship between the existing internal control mechanisms of the life insurers and performance, and also whether these internal control mechanisms are robust enough to effluence the level of performance?

\section{Statement of the problem}

A closer looks at the existing studies strongly suggested that despite the growing trend in internal control systems in financial institutions, there is little knowledge on the internal control practices that exist within life insurance companies in Ghana. Nevertheless, few studies have been carried out using the internal control system, but to the best of our knowledge they never touch on the relationship between COSO internal control mechanisms integrated frameworks and performance of life insurance industry (Badoo et al 2020; Amissah,2017; Dubihlela \& Nqala 2017; Collins, 2014 Kwasi \& Lokko, 2013). It is against this background that this study set out to fill this gap by answering the questions whether there is significant relationship between the existing internal control system of the life insurers and performance, and also whether these internal control mechanisms are robust enough to effluence the level of performance.

\section{The general objective of the study}

The main objective of this study is to examine the effect of internal control mechanisms on the performance of life insurers in Ghana

\section{Specific objective}

Specific objectives are to:

1. Assess the relationship between the internal control systems and performance of the life insurance companies in Ghana.

2. Evaluate how the internal control mechanisms contribute to the performance or otherwise of life insurers 
in Ghana.

\section{Significance of the study}

The findings of the current study will be of immense importance in the sense that it will assist regulators and management of life insurance companies to realize how internal control systems can affect its operations in terms of financial and non-financial performance. This study will further provide a valuable contribution to addressing challenges facing the financial performance of life insurance industry in Ghana and elsewhere.

\section{2.. Related literature}

The current study hinges on two main theories namely the agency theory and the contingency theory,

\section{The agency theory}

The agency theory posits that employees (agents) are autonomous and likely prone to increasing their personal gains at the detriment of employer (Sharma, 1997). Thus, this theory brings to fore the possible mechanisms that can be put in place in order to ensure optimum utilization of organisation's resources to the benefit of both the principal and the agents (Kisanyanya, 2018; Sharma, 1997; Jensen \& Meckling, 1976). This theory is therefore relevant to this study in that it helps in utilizing relevant control mechanisms in an organisation which forms a building block for this study.

\section{The contingency theory,}

The proponents of this theory argued that the optimal way in which a company could be organized depends on the kind of environment in which the company operates. The relevant of the contingency theory to the current study is that it brings to light the fact that firms interacts with its environment and are therefore not closed systems which could be structured without considering environmental characteristics and the manner in which they affect the company (Jokipii, 2006).

The current study uses the agency theory and contingency theory as foundation theories to examine the internal control systems of life insurers and its effect on firm's performance.

\section{Empirical review}

There are existing works that focus on the internal control system or firm performance. For instance, recently, Mbilla, Nyeadi, Gbegble and Ayimpoya (2020) investigate the effects of internal control systems on financial performance of listed banks in Ghana. In this study, 300 representatives from twelve listed banks were engaged. Descriptive and regression analysis was performed on the field data. The study result shows that information and communication have a weak significant effect on financial performance. There was no significant effect between monitoring and financial performance. The study therefore recommends that managers of listed Banks must invest more on information and communication in order to improve performance.

Ibrahim, Jianguo, Jaladi, Lartey and Amponsah (2019) explain the factors that affect the board's behavior when it comes to enhancing internal controls in financial institutions, particularly rural banks. The outcome of the study provided convincing evidence that, internal audit, external consultancy and the audit committee are dominant determinants of internal control and good governance.

Agbenyo, Jiang and Cobblah (2018) investigated the impact of government internal control systems on financial reporting quality in Ghana using Ghana Revenue Authority (GRA) as the case study. Specifically, the study sought to examine the nature and quality of financial reporting in the GRA, and to analyze the impact of government internal control systems on financial reporting quality. Both quota and simple random sampling techniques were used to select fifty (50) persons as the sample size of the study. The correlation matrix was used to establish a positive relationship between government internal control systems and financial reporting quality. The study find out that monitoring as an element of internal control system has a negative impact on the financial quality reporting but was however statistically significant. The study also revealed that with a unit increase in the collection performance quality of financial reporting of GRA will improve. The study recommended that the government should ensure that the internal control system is periodically monitored and evaluated.

Inusah and Abdulai (2015) in a study, assesses the internal controls in of the lands commission of Ghana. The study adopts the case study design using the officials of the commission in the Northern region of Ghana as the population. A sample of 30 officials of the commission was drawn for the study using the simple random combined with purposive sampling technique. Both primary and secondary data are used with the aid of questionnaires, interviews and documentary review. It was found that the existing controls are inadequate and a lot is required to ensure sound financial management in the sector. They recommended that financial controls are strengthened and enforced with authority and commitment; the internal audit function should also be reviewed by decentralizing to ensure that all activities are vetted before and not after the activities are undertaken.

On internal controls and performance, Khan, Channar and Shakri (2015) investigate the functionality of each of the five internal controls components, effectiveness of the control systems and their relationship with performance concluded that internal control effectiveness is strongest in private banks than public banks followed by Islamic banks and that internal control effectiveness has positive relationship with the financial performance of 
banks. Their study was based on the Indian financial sector and structured on a period of four years. The analysis was based on correlation test on the relationship.

Also, in a related study conducted by Ayagre, Appiah-Gyamerah and Nartey (2014), they evaluated the control environment and monitoring activities components of internal control systems of Ghanaian Banks using COSO's integrated framework and attributes of assessing the effectiveness of internal control systems. The study found out that, strong controls exist in the control environment and monitoring activities components of the internal control systems of banks in Ghana.

The study recommended that boards of banks in Ghana should not be complacent about the findings but should work hard to ensure continuous ongoing and separate internal control monitoring to ascertain that controls really exist and are functioning properly

Mwakimasinde, Odhiambo and Byaruhanga (2014) investigated the effect of internal control systems on the financial performance of sugarcane out grower companies in Kenya. They made limited use of the entire component of the COSO framework. This may create a conceptual gap. Again, there exists a contextual gap as the study focused on sugarcane out grower companies and not life insurance companies.

A related study by Mugo (2013) seek to find the effect of internal control practices on technical training institutions and realized that there is a significant relationship between internal control systems and financial performance.

Ayom (2013) posits that internal control affects performance. Using data in Uganda non-governmental organisation, Ayom (2013) came to a conclusion that implementation of internal control systems be reviewed regularly to ensure high level of performance of organisation since it has positive relationship to performance of such organisation. On the same note, the study found that fraud can be mitigated by effective internal control systems.

Also, Njanike, Mutengezanwa and Gombarume (2011) analysed factors that influence the internal controls in ensuring good corporate governance in financial institutions in developing economies with special reference to Zimbabwe. The study used the five components of the COSO framework. However, it did not relate it to firm performance. A geographical gap also exists as the study was not carried out from the Ghanaian perspectives.

Muraleetharan (2011) studied the impact of internal control on financial performance of selected private and public organisations. The key findings identified were based on the fact that internal control and financial performance are statistically significant in determining performance and that there is a positive relationship between internal control and financial performance, though there are no statistically significant relationship between control environment and information and communication and financial performance.

Clearly, almost the above studies suffers from geographical or contextual gaps, since these studies were not carried out from the insurance industry perspectives hence their outcome may not be entirely useful in the Ghanaian jurisdiction and context, hence the urgent need to carry out this current study.

\section{3.. Methodology \\ Research Design}

A cross-sectional survey was used to obtain responses from 198 respondents for this study out of the 200 questionnaires distributed to the various staff from selected 20 out of 23 life insurance companies in Ghana. These questionnaires were issued to the respondents through informal self-introduction and through online platform. The five independent variables used are part of the internal control systems framework developed by the COSO whereas the dependent variable relied on performance measures as a building block model. A correlation analysis and generalised regression model were employed to establish the relationship between the internal control systems and the performance of the life insurers in Ghana.

\section{Model specification}

The current study used the multiple regression analysis, as in equation (1), to establish the relationship between internal control system and performance of the life insurance firms in Ghana. The statistical relation of the COSO framework of internal control system and the performance of the Ghanaian life insurers are as follows.

$$
P F_{i}=\beta_{0}+\beta_{1} C A+\beta_{2} R A+\beta_{3} M A+\beta_{4} C E+\beta_{5} I C+\varepsilon_{i}
$$

where

$P F_{i}$ is performance of a life insurer, $\beta_{0} \cdots \cdots \beta_{5}$ are the population parameters of the model and, $\varepsilon_{i}$ is the disturbance term of the model. Please note that the following CA, RA, MA, CE and IC were defined earlier in the introduction section. 


\section{4.. Empirical results and discussions Descriptive analysis}

The first part of the questionnaire solicited personal information on the respondents. This part of the questions consists of sex, education level, department, and age of the respondents. This background information was very necessary because it gives the reader a certain level of assurance that the respondents have the ability or otherwise to provide the needed information. Tables 1 to 3 depict the personal information provided by the respondent which has been categorized into; sex, age groups, education levels, position held, age and length of service in the organization.

\section{Description of the Sex age groups of the respondents}

Table 1 highlight on the sex and age grouping of the respondents. There were 139 male representing $70.2 \%$ and a $59 \%$ female respondent representing $29.8 \%$. Clearly the life insurance industry working class was dominated by male. The sex grouping was further classified into age groups. From the Table 1, it could be noticed that about $42 \%$ of the respondents are at least 30 years old. This gives an indication that majority of the respondents are relatively mature.

Table 1: Sex and age groups of the respondents

\begin{tabular}{cccc}
\hline Age group & Male & Female & Total \\
\hline$<20$ & 10 & 21 & $31(15.66 \%)$ \\
$21-30$ & 35 & 18 & $53(26.77 \%)$ \\
$31-40$ & 53 & 11 & $64(32.32 \%)$ \\
$41-50$ & 36 & 9 & $45(22.73 \%)$ \\
$50>$ & 5 & 0 & $5(2.52 \%)$ \\
Total & $139(70.2 \%)$ & $59(29.8 \%)$ & $198(100 \%)$ \\
\hline
\end{tabular}

Source: Authors' computations

\section{Description of the respondents' level of formal educational qualifications}

The demographic section of the questionnaire also captured the level of formal education of the respondents which was categorized into four levels, namely certificate, diploma, undergraduate and master holders. Table 2 provides the respondents level of formal educational qualifications. From Table 2 it was revealed that out of the total respondents only 30 (15 per cent) of them are secondary certificate holders and majority of the respondents have either diploma, first degree (undergraduate) or postgraduate (master) degree holders, which represent 85 per cent. This means that the respondents are adequately qualified persons academically which provide an indication that the respondents' levels of communication are appreciable therefore can provide relatively reliable answers to the questionnaire.

Table 2: The respondents level of formal educational qualifications

\begin{tabular}{lccc}
\hline Educational level & Male & Female & Total \\
\hline Certificate & 21 & 9 & 30 \\
Diploma & 56 & 21 & 77 \\
Undergraduate & 49 & 21 & 70 \\
Postgraduate & 13 & 8 & 21 \\
Total & 139 & 59 & 198 \\
\hline
\end{tabular}

Source: Authors' computations

\section{Description of the positions held by the respondents in the organization}

The study solicited details about the positions held by the respondents in the organization for purposes of understanding their role in the organisation with reference to answers provided in achieving the objectives of the study. Details of the respondents' positions are captured in Table 3.

Closer looks at the Table 3 revealed that majority of respondents are fairly distributed across the various positions in the industry. About 36 per cent of the respondents are in junior staff category and about 64 per cent are in the manager, senior manager or director position in the organisation. From the Table 3 , it can be deduced that the majority of the respondents are directly involved in the implementation of the necessary internal control system of their organisation. Therefore, their responses are deemed to reflect what actually takes place in the organization. 
Table 3: Positions held by the respondents

\begin{tabular}{lcc}
\hline Position held & Frequency & Percentage \\
Junior staff & 71 & 35.86 \\
Managers & 64 & 32.32 \\
Senior manager & 41 & 20.71 \\
Director & 22 & 11.11 \\
& 198 & 100 \\
\hline
\end{tabular}

Source: Authors' computations

\section{Description of the respondents' years of service}

We attached important to level of the respondents' experience in the organization hence we solicited the years of experience or service the respondent had with the organisation.

Our survey revealed that 144 of the respondents representing $73 \%$ have served in the organization for at least 5 year. The number of years of service demonstrates the experience and continuity as well as the understanding of the internal controls which have been put in place.

Description of the reliability and validity of the research instrument used.

Table 4depict the various components of the COSO internal control integrated framework and the firm performance as used in this study. It could be observed that the data used for all the variables under consideration are negatively skewed with repective positive Kutosis, this indicate that the data used are relatively normally distributed. The Crobach alpha value (CAV) and composite reliability vales (CRV) together with the average variance extracted (AVE) values establish the validity and reliability of the research instrument used.

Table 4: Skewness, Kurtosis, Cronbach and Average variance and reliability values.

\begin{tabular}{lllllcl}
\hline Variable & Skewness & Kurtosis & CAV & CRV & No of items & AVE \\
\hline F & -0.1387 & 0.2176 & 0.8312 & 0.8814 & 4 & 0.5643 \\
CA & -0.1187 & 2.5529 & 0.7450 & 0.7954 & 4 & 0.5456 \\
RA & -0.0216 & 0.4251 & 0.8563 & 0.8563 & 4 & 0.5543 \\
MA & -0.2173 & 2.1245 & 0.8762 & 0.9167 & 3 & 0.5776 \\
CE & -0.1139 & 2.2126 & 0.6967 & 0.7596 & 5 & 0.6543 \\
IC & -0.0225 & 0.1067 & 0.7882 & 0.8383 & 3 & 0.5432 \\
\hline
\end{tabular}

Source: Authors' computations

\section{The correlations analysis}

The correlations were used to establish the linear relationship between the dependent and independent variables. The Pearson's correction test was used to execute this as shown Table 5. It could be shown in Table 5 that, almost all the independent variables have strong positive correlation with the dependent variable, indicating that the independent variables are very good in determining the outcome of the dependent variable. Also, the correlation among the independents variables very low an indication of absence of multicollinearity.

Table 5: Correlation analysis of variables of interest

\begin{tabular}{lllllll}
\hline & PF & CA & RA & MA & CE & IC \\
\hline PF & 1.0000 & 0.5218 & 0.7124 & 0.7612 & 0.6582 & 0.7239 \\
CA & 0.5218 & 1.0000 & 0.2183 & 0.4482 & 0.2183 & 0.2191 \\
RA & 0.7124 & 0.2183 & 1.0000 & 0.3219 & 0.3319 & 0.1196 \\
MA & 0.7612 & 0.4482 & 0.3219 & 1.0000 & 0.1175 & 0.5211 \\
CE & 0.6582 & 0.2183 & 0.3319 & 0.1175 & 1.0000 & 0.3255 \\
IC & 0.7239 & 0.2191 & 0.1196 & 0.5211 & 0.3255 & 1.0000 \\
\hline
\end{tabular}

Source: Authors' computations

\section{The coefficient of multiple determination}

In order to assess the fitness of our research model, we computed the coefficient of multiple determination, also known as the coefficient of determination as shown in Table 6. From the Table 6, it can be observed that the explanatory power of the internal control systems (that is the independent variables) was $97 \%$ with an adjusted Rsquare of approximately $94 \%$. This implies that about $94 \%$ of the variation in the performance of the life insurance companies is explained by the internal control mechanisms variables, and about $6 \%$ is attributable to other factors. The F-statistic is significant indicating the fitness of our model. 
Table 6: The coefficient of multiple determination

Model summary

\begin{tabular}{lllll}
\hline Model & R & R-square & Adjusted R-square & Std. Error of the estimate \\
1 & $0.971425^{\mathrm{a}}$ & 0.943666 & 0.937318 & 0.796512 \\
\hline
\end{tabular}

a. Predictors: (constant), CA, RA, MA, CE and IC

Source: Authors' computations

Table 7: ANOVA

Analysis of variance (ANOVA ${ }^{a}$ )

\begin{tabular}{|c|c|c|c|c|c|c|}
\hline${ }^{1}$ Model & & $\mathrm{df}$ & Sum of squares & Mean square & $\mathrm{F}$ & Sig. \\
\hline Regression & 5 & & 11.07765 & 2.215531 & 3.968329 & $0.000^{b}$ \\
\hline Residual & 192 & & 107.1942 & 0.558303 & & \\
\hline Total & 197 & & 118.2719 & & & \\
\hline
\end{tabular}

a. Dependent variable: Performance

b. Predictors: (constant), CA, RA, MA, CE and IC

Source: Authors' computations

\section{Regression Analysis}

We conducted a multiple regression analysis (See Table 8) so as to determine the relationship between performance and the internal control system variables investigated in the current study. From Table 8, the estimated regression model that establishes the relationship between the internal control systems and that of the life insurance performance is shown in equation (2).

$$
P F=1.9074+0.15955 C A+0.1746 R A+0.1981 M A+0.1726 C E+0.1399 I C
$$

It could be observed from Table 8 that the parameters of the model fitted are significant at the $5 \%$ significant level. This can be verified by using the standard error test which states that for a parameter to be significant at the $5 \%$ significant level, the standard error should be less than half the parameter value. For instance, on average, a unit increase in the control activities (CA) of an insurance firm will increase the firm performance by 0.1595 .

Table 8: Multiple Regression

\section{Coefficients $^{\mathrm{a}}$}

\begin{tabular}{llllcc}
\hline \multicolumn{5}{l}{ Unstandardized coefficients } & \multicolumn{2}{l}{$\begin{array}{l}\text { Standardized } \\
\text { coefficients }\end{array}$} \\
\hline${ }^{1}$ Model & B & Std. Error & Beta & t & Sig. \\
(Constant) & 1.90744 & 0.36495 & & 5.2265366 & 0.000 \\
CA & 0.15955 & 0.06001 & 0.14903 & 2.6586349 & 0.021 \\
RA & 0.17464 & 0.07011 & 0.28805 & 2.4908645 & 0.001 \\
MA & 0.19806 & 0.09106 & 0.03284 & 2.1751172 & 0.000 \\
CE & 0.17264 & 0.05506 & 0.29993 & 3.1352789 & 0.001 \\
IC & 0.13987 & 0.06192 & 0.23758 & 2.2589674 & 0.001 \\
\hline
\end{tabular}

a. Dependent variable: Performance

Source: Authors' computations

\section{Findings}

The main objective of this current study is to empirically investigate the relationship between the performance and internal control, and also assess the effect of internal control mechanisms on performance of life insurance companies in Ghana using the COSO integrated framework.

The findings from the study showed that the sampled firms relatively adhered to the internal controls procedures put in place by managements, and there is significant positive correlation between the components of COSO internal controls integrated framework and performance of the selected life insurance companies.

The study further revealed that internal control mechanisms have positive and unique contribution to explaining the performance of life insurance companies in Ghana. This agreed with the findings of Amissah (2017), Hakkak and Ghodsi (2015), and Badoo, et al (2020), but did not agree with the study carried out by Kwasi and Lokko, (2013).

\section{5.. Conclusion and Recommendations}

Emanating from the findings of the current study, it is concluded that the financial performance are positively related to the internal control mechanisms and have significant impact on performance of life insurance companies in Ghana. 
We recommend that life insurance firms improve upon the core principles of the various components of the COSO internal control system integrated framework. For instance, with regards to the control environment, the firms should demonstrate commitment to integrity and ethical values; they should exercises oversight responsibility, establish structure, authority, and responsibility, demonstrates commitment to competence and enforce accountability throughout the firms.

Also, with regards to the risk assessment mechanism, we recommend that the firm should be strengthen to identify and analyzes risk as well as identification of significant change. The firms should also continue to deploy control activities through policies and procedures taking into consideration the relevant information and its dissemination. Insurance companies are also encouraged to continue with continue monitory mechanisms.

\section{References}

Abdi, A.D., 2015. The impact of internal control system on financial performance in Mogadishu private banks (Case study of some selected private banks in Mogadishu). Unpublished Master's Thesis, Horseed International University.

Agbenyo,W., Jiang, Y. \& Cobblah, P.K. (2018). Assessment of government internal control systems on financial reporting quality in Ghana: A case study of Ghana revenue authority. International Journal of Economics and Finance; 10(11): 40-50

Amissah, A. (2017). Effect of Internal Control Systems on Performance of Companies in the Insurance Industry in Ghana. Masters of Commerce in Accounting, Department of Accounting and Finance, School of Business, University of Cape Coast.

Ayagre P, Appiah-Gyamerah I, Nartey J.(2014). The Effectiveness of Internal Control Systems of Banks. The Case of Ghanaian Banks. International Journal of Accounting and Financial Reporting ; 4(2): 377.

Ayom, A., (2013). Internal Controls And Performance in Non-Governmental Organizations: A Case Study of Management Sciences for Health South Sudan, A research report submitted to the faculty of business management in partial fulfillment of the requirements for the award of bachelor's degree in business administration of Cavendish University Uganda.

Badoo, D.O.,Hammond,H. \& Oppong, F. (2020). Assessment of Internal Control Systems of Technical Universities in Ghana. Journal of Finance and Accounting. 8(2): 64-72.

Bourne, M., Neely, A., Mills, J., \& Platts, K. (2003). Implementing Performance Measurement Systems: A literature Review. International Journal of Business Performance Management, 5(1), 1-24

Brennan, N. M., \& Solomon, J. (2008). Corporate Governance, Accountability and Mechanisms of Accountability: An Overview. Accounting, Auditing \& Accountability Journal, 21(7), 885-906.

Channar, Z. A., Khan, M., \& Shakri, I. H. (2015). Internal Control Effectiveness and its Relationship with Financial Performance. Formerly Journal of Management and Social Sciences, 11(2), 92-107.

Chebungwen, N. \& Kwasira (2014). An Assessment Of Internal Control System on Financial Performance in Tertiary Training Institutions in Kenya: A Case Study of African Institute of Research and Development Studies. International Journal of Science and Research : 2319-7064

Collins, O.O.(2014). Effect of Internal Control on Financial Performance of Micro-Finance Institutions in Kisumu Central Constituency. Kenya. Journal of Scientific Research and Essay. 3:, 139-155.

Committee of Sponsoring Organization of Treadway Commission [COSO] (2013). The updated COSO internal control framework. Retrieved, from http://www.protiviti.com/.../Updated-COSO-Internal-ControlFramework

Dubihlela, J., \& Nqala, L. (2017). Internal Controls Systems and the Risk Performance Characterizing Small and Medium Manufacturing Firms in the Cape Metropole. International journal of business and management studies, 9(2), 87-103.

Eniola, O. J., \& Akinselure, O. P. (2016). Effect of Internal Control on Financial Performance of Firms in Nigeria: A Study of Selected Manufacturing Firms. IOSR Journal of Business and Management, 18(10), 80-85.

Epstein, J., and McFaralan, W. (2011). Joining A Nonprofit Board: What you need to know. Jossey-Bass Publications.

Hakkak, M., \& Ghodsi, M. (2015). Development of a Sustainable Competitive Advantage Model Based on Balanced Scorecard. International Journal of Asian Social Science, 5(5), 298-308.

Ibrahim, R., Jianguo, D., Jaladi, S. R., Yao, P. L., \& Kwabena, A. C. (2019). Determinants of Board Contribution to Internal Controls and Good Governance: Evidence of Rural Banks in Ghana. Journal of Public Administration and Governance, 9(4), 85-100

Inusah, A. M., \& Abdulai, S. (2015). Assessing internal Financial Controls of the Lands Commission of Ghana. European Journal of Business, Economics and Accountancy, 3(3), 51-65.

Jensen, M. C., \& Meckling, W. H. (1979). Theory of the Firm: Managerial Behavior, Agency Costs, and Ownership Structure. In Economics social institutions (pp; 163-231). Springer, Dordrecht. https://doi.org/10.1007/978-94-009-9257-3_8 
Jokipii, A. (2006). The Structure and Effectiveness of Internal Control: A Contingency approach. Doctoral dissertation, University of Vaasa, Finland. Retrieved from http://www.uva.fi/materiaali/pdf/isbn_952- 476161-0.pdf

Kaplan. (2014). Performance Management: A complete study text. Berkshire, England: Kaplan Publishing.

Kinyua JK, Gakure R, Gekara M, Orwa G (2015). Effect of Internal Control Environment on the Hussaini Umar et. al., /.International Journal of Innovative Finance and Economics Research; 3(4): 29-48.

Kisanyanya, G. A. (2018). Internal Control Systems and Financial Performance of public Institutions of Higher Learning in Vihiga County, Kenya. Doctoral dissertation, Kenyatta University.

Kwasi, C. C. P. \& Lokko, G. W. (2013). Evaluate the Significance of Internal Control System in the Rural Banking Sector International Conference on Technology and Business Management, All Nations University, Ghana.

Mary M, Albert O. \&, Byaruhanga J. (2014). Effects of internal control systems on financial performance of sugarcane outgrower companies in Kenya. IOSR Journal of Business and Management 16(12): 62-73.

Mawanda, S. P. (2008). Effects of Internal Control System on Financial Performance in Uganda's Institution of Higher Learning in Uganda. A Postgraduate Dissertation (2008).

Mbilla, S. A. E., Nyeadi, J. D., Gbegble, M. K., \& Ayimpoya, R. N. (2020). Assessing the Impact of Monitoring, Information and Communication on Banks Performance in Ghana. Asian Journal of Economics, Business and Accounting, 58-71.

Mugo, J. M. (2013). Effects of Internal Controls on Financial Performance of Technical Training Institutions in Kenya. (Master"es dissertation, University of Nairob, Kenya). Retrieved from http://epository yuonbi.ac.ke/bit stream/handle/11295/59324

Muraleetharan, P. (2011). Internal Control and its Impact on Financial Performance of Public and Private Organizations in Jaffna District.

Mwakimasinde, M., Odhiambo, A., \& Byaruhanga, J. (2014). Effects of Internal Control Systems on Financial Performance of Sugarcane Out-grower Companies in Kenya. Journal of Business and Management, 16(12), 62-73.

Njanike, Mutengezanwa and Gombarume (2011). Internal Controls in ensuring good Corporate Governance in Financial Institutions. Annals of the University of Petroşani, Economics, 11(1): 187-196

Njeri, C. K. (2014). Effect of Internal Controls on the Financial Performance of Manufacturing Firms in Kenya. Master's Dissertation, University of Nairobi, Kenya.

Palfi, C., \& Muresan, M. (2009). Survey on Weaknesses of Banks Internal Control Systems. Journal of International Finance and Economics, 9(1), 106-116.

Sharma, A. (1997). Professional as Agent: Knowledge Asymmetry in Agency Exchange. Academy of Management review, 22(3), 758-798.

Smith, M. (2005). Performance Measurement and Management: A Strategic Approach to Management Accounting. Thousand Oaks, CA: Sage Publications Inc.

Widyaningsih, A. (2015). The Influence of Internal Control System on the Financial Accountability of Elementary schools in Bandung, Indonesia. Research Journal of Finance and Accounting, 6(24), 89-96.

Yousef, A.B.(2017). The Impact of Internal Control Requirements on Profitability of Saudi Shareholding Companies. https://doi.org/10.1108/IJCOMA-04-2013-0033 